\title{
Dauginis galvinių nervų pažeidimas, sergant Churgo-Strausso sindromu: klinikinis atvejis
}

\section{G. Rutkauskaite்* \\ R. Masaitiené* \\ J. Dadoniené** \\ D. Jatužis*}

*Vilniaus universitetas, Medicinos fakultetas, Klinikinès medicinos institutas, Neurologijos ir neurochirurgijos klinika; Vilniaus universiteto ligonine Santaros klinikos,

Neurologijos centras

**Vilniaus universitetas, Medicinos fakultetas, Sveikatos mokslu institutas; Vilniaus universiteto ligonine Santaros klinikos, Reumatologijos centras

\begin{abstract}
Santrauka. Churgo-Strausso sindromas (CSS), dar žinomas kaip eozinofilinė granulomatozė su poliangitu, yra smulkiujjų ir vidutinių kraujagyslių vaskulitas, pradinėse stadijose pasireiškiantis lètiniu rinosinusitu, bronchine astma ir hipereozinofilija periferiniame kraujyje. Sindromą pirmą kartą 1951 m. aprašė Jacobas Churgas ir Lotte Straussas. Histologiškai stebima eozinofilinè infiltracija audiniuose, nekrotizuojantis vaskulitas ir eozinofilinis-granulomatozinis uždegimas. Susirgimo patogenezė nėra iki galo žinoma, tačiau nustatytas genetinis polinkis, ryšys su HLA-DRB4. Iki $40 \%$ pacientų nustatomi antineutrofiliniai citoplazminiai antikūnai (ANCA), todèl CSS priskiriamas ANCA asocijuotų vaskulitų grupei. CSS gali pažeisti beveik bet kurią organų sistemą, taip pat ir nervų. Nervų sistemos pažeidimai nustatomi iki 70 \% CSS pacientų, nors galvinių nervų pažeidimas yra ypač retas. Pacientai gydomi gliukokortikoidais, imunosupresantais. Šiame straipsnyje pristatomas CSS sergančios $68 \mathrm{~m}$. moters klinikinis atvejis, kuriai, praejjus $12 \mathrm{~m}$. nuo ligos pradžios, pasireiškè dauginès galvinių nervų mononeuropatijos.
\end{abstract}

Raktažodžiai: Churgo-Strausso sindromas, eozinofilinė granulomatozė su poliangitu, ANCA asocijuotas vaskulitas, galvinių nervų dauginės mononeuropatijos, polineuropatija.

\section{IŽANGA}

Churgo-Strausso sindromas (CSS), dar žinomas kaip eozinofilinė granulomatozė su poliangitu, yra retas autoimuninis susirgimas, pasireiškiantis bronchine astma, eozinofilija bei sisteminiu nekrotizuojančiu smulkiujų ir vidutinių kraujagyslių vaskulitu. Pirmieji CSS aprašè $1951 \mathrm{~m}$. patologai Jacobas Churgas ir Lotte Straussas, pavartoję terminą „alerginè granulomatozė“ [1]. Dẻl dažno antineutrofilinių citoplazminių antikūnų (ANCA) nustatymo, kurie randami 30-40 \% CSS atvejų, bei smulkiujų kraujagyslių pažeidimo, CSS priskiriamas ANCA asocijuotų vaskulitų grupei (AAV). AAV taip pat priskiriami mikroskopinis poliangitas ir granulomatozė su poliangitu (Vegenerio granulomatozè) [2]. Išskiriamos trys CSS pasireiškimo fazès: 1) prodrominè arba alerginè fazè, kuriai būdinga bronchinè astma ir rinosinusitas, 2) eozinofilinè fazè, kurios metu stebima periferinè eozinofilija ir organų pažeidimas, 3) vaskulitiné fazė su smulkiųjų kraujagyslių vaskulito klinikiniais požymiais. Audinių ir organų pažeidimas gali ịvykti dèl nekrotizuojančio vaskulito ir eozinofilų aktyvacijos, proliferacijos, granulomų susidarymo organuose bei granuliu citotoksinio baltymo išsiskyrimo [3]. CSS gali pažeisti daugelị organų, tarp jų - plaučius, širdị, odą, virškinamajji traktą, taip pat ir nervų sistemą.

\section{KLINIKINIS ATVEJIS}

$68 \mathrm{~m}$. pacientė $2018 \mathrm{~m}$. spalio mèn. stacionarizuota planine tvarka ištyrimui ị Vilniaus universiteto ligoninès Santaros

(C) Neurologijos seminarai, 2019. Open Access. This article is distributed under the terms of the Creative Commons Attribution 4.0 International License CC-BY 4.0 (http://creativecommons.org/licenses/by/4.0/), which permits unrestricted use, distribution, and reproduction in any medium, provided you give appropriate credit to the original author(s) and the source, provide a link to the Creative Commons license, and indicate if changes were made. 
klinikų (VUL SK) Nervų ligų skyrių dẻl sutrikusio matymo dešine akimi, dvejinimosi, nusileidusių vokų, šaudančio pobūdžio skausmo pakaušio srityje, plintančio dešine galvos puse iki dešinès akies, sutrikusios kalbos, liežuvio nukrypimo.

Pacientei prieš 12 metu (2006 m.) VUL SK Reumatologijos skyriuje buvo diagnozuotas Churgo-Strausso sindromas. Liga manifestavo bronchine astma, vèliau prisidèjo galūniu polineuropatija ir odos bèrimai, buvo rasti teigiami ANCA. Gydymui buvo paskirtas prednizolonas ir azatioprinas, pastarasis, pagerèjus būklei, nutrauktas. Palaikomajam gydymui pacientè vartojo prednizolono $15 \mathrm{mg}$ per dieną. $2012 \mathrm{~m}$. pašalintas tiesiosios žarnos piktybinis navikas. $2015 \mathrm{~m}$., progresuojant kojų polineuropatijai, sustiprẻjus dusuliui dèl bronchinès astmos, plintant poodinèms kraujosruvoms, atnaujintas azatioprino vartojimas, tęsiant gydymą prednizolonu.

Kelerius pastaruosius metus pacientė jautė progresuojantị kojų silpnumą. $2018 \mathrm{~m}$. gegužès mènesį atsirado dvejinimasis, kalba tapo suvelta, todèl pacientè buvo stacionarizuota pagal gyvenamają vietą į Neurologijos skyrių. Atliktame galvos smegenų neurovizualiniame tyrime reikšmingų pakitimų nerasta. Diagnozuotas atitraukiamojo nervo dešinėje ( $n$. abducens) pažeidimas, lètinės galvos smegenų išemijos pablogèjimas su dizartrija, pakaušinio nervo dešinèje (n. occipitalis) neuropatija. Pacientè gydyta mikrocirkuliaciją gerinančiais vaistais ir tęstas nekoreguotas CSS gydymas. Gydant būklè pagerèjo - atsistatė kalba, išnyko dvejinimasis. $2018 \mathrm{~m}$. liepos mènesị būklè vèl pablogèjo - staiga sutriko regejjimas dešine akimi, epizodiškai dvejinosi vaizdas, sutriko kalba, rijimas, atsirado liežuvio nuokrypis. Moteris pakartotinai stacionarizuota pagal gyvenamają vietą į Neurologijos skyrių. Itarus miasteniją, atlikta ritminè nervo stimuliacija, tačiau reikšmingo amplitudès dekremento negauta, kompiuterinès tomografijos tyrime tiek plaučiuose, tiek tarpuplautyje specifinių patologiniu pakitimų nerasta. Kraujo tyrimuose antikūnų prieš acetilcholino receptorius nerasta. Kraujo tyrimų rezultatai, tarp jų ir kreatininkinazè, skydliaukès veiklos hormonai, buvo normalūs. Tačiau po neostigmino $0,5 \mathrm{mg}$ injekcijos stebètas teigiamas efektas - trumpam palengvèjo kalbejjimas ir rijimas, sumažèjo dvejinimasis, todèl ilgalaikiam gydymui buvo paskirta piridostigmino $60 \mathrm{mg} 2$ kartus per dieną, tęsiant metilprednizolono ir azatiaprino vartojimą. Nepaisant skirto gydymo, pacientès būklè negerèjo. Ambulatoriškai konsultuota neurologo, rekomenduota padvigubinti piridostigmino dozę, tačiau teigiamo efekto nebuvo, todèl $2018 \mathrm{~m}$. rugsèjį stacionarizuota ị VUL SK Nervų ligų skyrių.

VUL SK Nervų ligų skyriuje apžiūros metu stebèta viršutinių vokų ptozė ir apatinių vokų paburkimas (pakitimai ryškesni dešinėje pusėje), junginès chemozè, išverstakumas, vyraujantis dešinejje; riboti akių horizontalūs judesiai: žiūrint tiesiai - dešinè akis nukrypo ị viršų ir medialiai, kreipiant ị kairę akių obuolius - kairės akies neprivedè ị lateralinę pusę, o žiūrint ị dešinę - dešinès akies neprivedè ị lateralinę pusę ir akis kilo kiek aukštyn; taip pat nedaug riboti buvo ir vertikalūs akių obuoliu judesiai (1 pav., A-E).
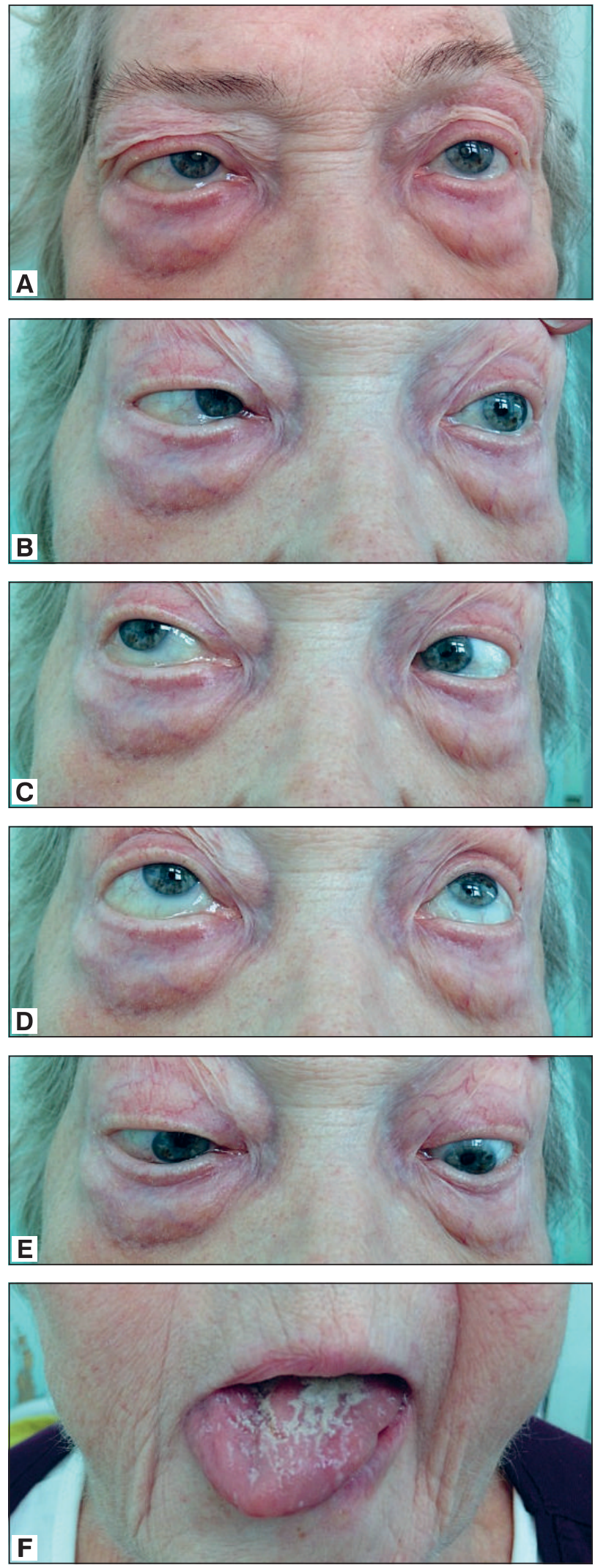

1 pav. (A) pacientẻ žiūri tiesiai, (B) i kairę pusę, (C) į dešinę pusę, (D) ị viršų, (E) i i apačią; (F) liežuvio atrofija ir deviacija ị dešinę pusę.

Pacientė nurodė dvejinimąsi visomis kryptimis. Stebèta liežuvio deviacija ị dešinę pusę, dešinès liežuvio pusės hipotrofija (1 pav., F). Palpuojant buvo skausminga pakauši- 
nio nervo taškų projekcija dešinėje. Rasti vangūs užpakalinès ryklès sienelès ir minkštojo gomurio refleksai. Stebėta difuzinè raumenų hipotrofija, ypač ryški kojose, plona ir sausa oda. Nustatytas polineuropatinio tipo jutimo sutrikimas kojose. Apatinio žandikaulio, sprando ir rankų raumenų jèga buvo gera. Kojų pati nepakèlè, kairès kojos nenulaikè dèl kairiojo sąnario patologijos. Sausgyslių refleksai galūnėse - simetriški, distaliniai - labai žemi, aiškių patologinių refleksų nebuvo.

Pacientei atlikta galvos smegenų magnetinio rezonanso tomografija (MRT), kurioje rasta kraujagyslinė leukoencefalopatija, abipusė akių obuolių proptozė, akiduobių minkštuju audinių infiltracija. Pakartotas neuroraumeninès jungties tyrimas ritminès stimuliacijos būdu - patologinis $\mathbf{M}$ atsako dekrementas prieš ir po krūvio negautas. Elektroneuromiografijos tyrimo metu stebèta sensomotorinė kojų aksonopatija. Atliktas kaklo minkštụjų audinių ir skydliaukès ultragarsinis tyrimas dèl galimų spaudimo priežasčių - patologinių darinių nestebėta. Paciente konsultuota gydytojo otorinolaringologo dèl disfonijos - patologijos nerasta. Oftalmologinės apžiūros metu nustatyta, kad dešine akis jautri tik šviesai, diagnozuota regos nervo (n. opticus) dešinèje subatrofija.

Atlikta galvos smegenų kompiuterinè tomografija (KT) su angiografijos režimu, siekiant ekskliuduoti kaverninio sinuso (sinus cavernosus) trombozę ar karotikokaverninę fistulę. Tyrimo metu kaverninis sinusas kontrastavosi tolygiai, patologinės kraujotakos požymių akiduobėse nestebèta, matyti sustorèję, infiltruoti dešinèje apatinio ir šoninio tiesiųjų raumenų ( $m$. rectus inferior, $m$. rectus lateralis) pilveliai (2 pav.).

Pacientẻ apžiūrèta gydytojo reumatologo. Multidisciplininio aptarimo metu nuspręsta, kad neurologiškai randami pakitimai: kojų sensomotorinė neuropatija, naujai atsiradę dauginiai galvinių nervų pažeidimai (regos nervo (n. opticus) išeminè neuropatija, judinamojo akies nervo (n. oculomotorius), liežuvinio ryklès nervo (n. glossopharyngeus), klajoklio nervo (n. vagus), poliežuvinio nervo (n. hypoglosus) neuropatijos dešinèje) yra sąlygoti CSS ir vertinami kaip šios reumatologinès ligos neurologinė manifestacija. Dèl multikomorbidiškumo rekomenduota koreguoti gliukokortikoidų dozę ir papildomai skirta hidrochlorokvino $200 \mathrm{mg} \times 2$ kartus per dieną.

Būklei pagerejus, pacientė išleista ị namus toliau gydytis ambulatoriškai, jos būklę stebint reumatologui. Atkreiptinas dėmesys, kad nei eozinofilijos, nei ANCA antikūnų šiuo ligos epizodu kraujyje nebuvo stebėta. Laboratoriniai nukrypimai, būdingi šiai ligai, buvo stebimi tik ligos pradžioje $2006 \mathrm{~m}$.

\section{APTARIMAS}

Sergant CSS, gali būti pažeista tiek periferinè, tiek centrinė nervų sistema.

Periferinė polineuropatija (PN) yra dažniausias nervụ sistemos pažeidimo požymis, nustatomas apie $70 \%$ CSS sergančių pacientų [4-6]. Pacientus vargina sensorinis de-

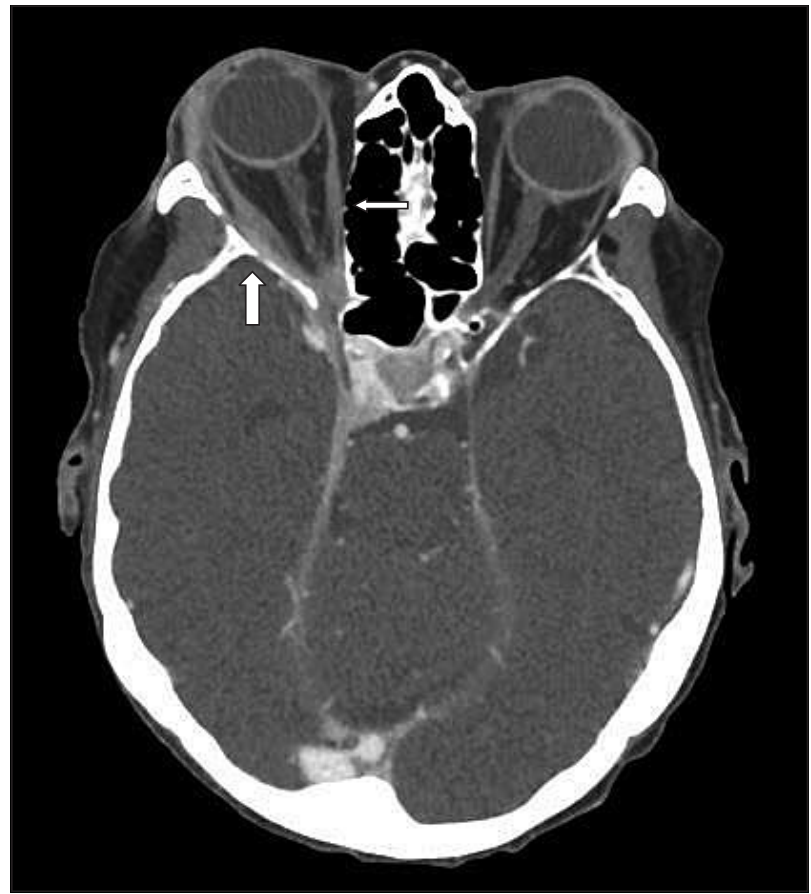

2 pav. Galvos KT

Rodyklès nurodo $m$. rectus inferior ir $m$. rectus lateralis sustorèjusius pilvelius.

ficitas ir neuropatinis skausmas [7]. Nustatoma simetrinė arba asimetrinè polineuropatija, apimanti sensorinius ir (ar) motorinius nervus. Dažnai vyrauja aksoninis, bet stebimas ir mišrus pažeidimas su denervacija bei raumenų atrofija. Rečiau gali pasireikšti mononeuropatijos arba dauginès mononeuropatijos [8].

Hye-Jin Cho ir kt. 2017 m. Pietų Korejjoje publikavo tyrimą, kuriame analizavo periferinės nervų sistemos pažeidimą, sergant CSS [9]. I tyrimą buvo ịtrauktas 71 pacientas, atitinkantis Amerikos reumatologų kolegijos nustatytus kriterijus ( 3 pav.). 46 pacientams nustatyta polineuropatija, kuri patvirtinta elektrofiziologiškai. ANCA buvo nustatyti $11 \% \mathrm{PN}(+)$ pacientų, o visiems $\mathrm{PN}(-)$ pacientams antikūnų neaptikta. Be PN simptomų, du pacientai turejo veidinio nervo pažeidimą, o vienas - vestibulinio nervo pažeidimą. PN(-) pacientams nebuvo nustatytas centrinės nervų sistemos (CNS) ar galvinių nervų pažeidimas. Vienas $\mathrm{PN}(+)$ pacientas turejo centrinès tinklainès arterijos okliuziją, susijusią su vaskulitu. Keturiasdešimt keturi tiriamieji PN grupejje $(95,6 \%$ ) skundèsi disestezija ar neuropatiniu skausmu.

CNS pažeidimas, sergant CSS, yra retesnis, jo dažnis skirtingose studijose nurodomas nuo 6 iki $39 \%$ [3, 10]. Pagrindinès CNS apraiškos, minimos literatūroje, yra galvos smegenų infarktas, subarachnoidinė ir intracerebrinė hemoragijos [11], galvos smegenų veninių ančių trombozè [8]. CNS pažeidimo patofiziologija nèra gerai žinoma, bet manoma, kad kompleksiškai veikia keli mechanizmai, nes ligos pasireiškimas siejamas su vaskulitu, kraujo eozinofilija ir audinių eozinofiline infiltracija, miokarditu arba endomiokardo fibroze, sąlygojančiais embolizaciją [11]. 

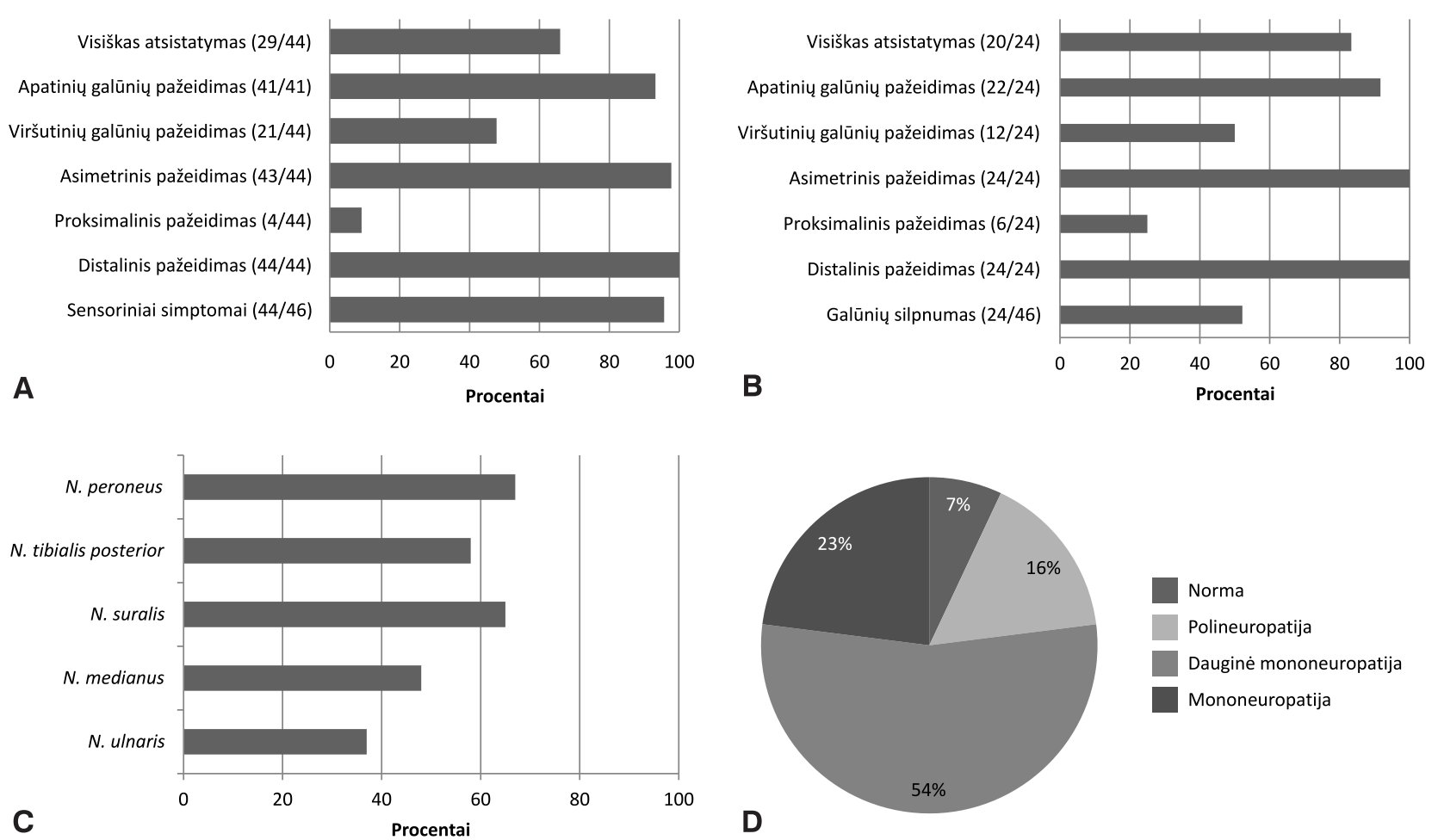

3 pav. Klinikinė ir elektrofiziologinė periferinės nervų sistemos pažeidimų charakteristika, sergant CSS

Motorinių polineuropatijų charakteristika (A), sensorinių polineuropatijų charakteristika (B), periferinių mononeuropatijų pasireiškimas $(\mathrm{C})$, periferinès nervų sistemos pažeidimų procentinis išsidėstymas (D).

Intraventrikulinè (IVH), subarachnoidinè (SAH) ir (arba) intracerebrinè hemoragijos (ICH) nustatomos retai 6-10\% CSS atvejų [12]. Tikslus CSS asocijuotos ICH mechanizmas nežinomas. Publikacijose minimi keli mirtini atvejai, kai CSS pacientams ịvyko IVH, SAH ir buvo nustatytas šoninio skilvelio gyslinio rezginio (plexus choroideus) vaskulitas [13]. Be to, pastebėtas ryšys tarp hipertenzijos ir ICH, kuri dažnai nustatoma CSS pacientams [12]. Manoma, kad hipertenzija atspindi inkstų funkcijos ar autonominès nervų sistemos pažeidimą [13, 14].

Galvinių nervų pažeidimas nustatomas 3,1-14 \% sergančiụjų CSS [15]. Literatūroje aprašomos galvinių nervų mononeuropatijos, išeminè optinè neuropatija, optinis neuritas, tinklainès arterijų okliuzija $[10,15,16]$. Pažeidimas greičiausiai atsiranda dèl galvos smegenų ar galvinių nervų branduolių išemijos ir nervus maitinančių kraujagyslių (vasa nervorum) vaskulito [11].

2017 m. R. Andre su kolegomis atliko metaanalizę, kurioje buvo nagrinèti pacientu CNS pažeidimai, sergant CSS [11]. Iš viso įtraukti 88 pacientai: 42 vyrai (48\%) ir 46 moterys (52\%), kurių amžiaus vidurkis - 49,9 m. (lentelè). Astma diagnozuota $97 \%$ pacientų, eozinofilija - $98 \%$, periferinè neuropatija - $55 \%$, širdies pažeidimas $-41 \%$. Teigiami p-ANCA ir (ar) anti-MPO nustatyti $54 \%$ tiriamuju (38/71). Pagrindiniai neurologiniai pažeidimai buvo: išeminis smegenų infarktas (52 \%), ICH ir (ar) SAH (24\%), regos aštrumo praradimas $(33 \%, 15$ pacientų nustatytas optinis neuritas, 9 - centrinès tinklainès arterijos okliuzija, 4 - žievinis aklumas) ir galvinių nervų parezès (21\%). Dažniausiai nustatytas veidinio nervo pažeidimas (38 \%).
Mūsų aprašytu klinikiniu atveju stebètas dauginis galvinių nervų pažeidimas (regos, judinamasis akies, liežuvinis ryklès, klajoklis, poliežuvinis nervai), kojų sensomotorinè polineuropatija ir akių judinamujjų raumenų infiltracija. Kadangi miastenijos diagnozė buvo paneigta (atlikta ritminė nervo stimuliacija - neigiama, nerasti antikūnai prieš acetilcholino receptorius), nesant kitų priežasčių, galinčių paaiškinti pažeidimus, neurologiniai simptomai sieti su retomis CSS komplikacijomis. Akių judesių sutrikimas galèjo îvykti dèl judinamojo akies nervo neuropatijos, branduolio išemijos, sąlygotos vaskulito, ir (ar) akių judinamujų raumenų eozinofilinės infiltracijos, kas paaiškintų fliuktuojančius akių judesių sutrikimus, teigiamą dinamiką po paskirto gydymo gliukokortikoidais didesnemmis nei vidutinès dozėmis. Be galvinių nervų pažeidimo, ligonei diagnozuota ir dažnesnè CSS neurologinė manifestacija progresuojanti kojų polineuropatija, kuri nustatomas iki 70 \% CSS sergančiu pacientų.

Praktiniame neurologo darbe, susidūrus su daugine galvinių nervų neuropatija, reikètų nepamiršti sisteminių vaskulitų, kurie gali sukelti tokius nervų sistemos pažeidimus.

\section{IŠVADOS}

- Eozinofilinè granulomatozè su poliangitu, arba Churgo-Strausso sindromas, yra reta autoimuninè liga, tačiau dažnai pasireiškia sunkiu sisteminiu nekrotizuojančiu vaskulitu ir gali pažeisti beveik bet kurią organų sistemą, taip pat ir nervų sistemą. 
Lentelè. Nervų sistemos pažeidimai, sergant Churgo-Strausso sindromu

\begin{tabular}{|c|c|c|c|}
\hline Charakteristika & $\begin{array}{l}\text { Pacientai } \\
(\mathbf{n}=\mathbf{8 8})\end{array}$ & $\begin{array}{l}\text { Radiologiniai pakitimai KT ir (ar) MRT } \\
\text { vaizduose }\end{array}$ & $\begin{array}{c}\text { Pacientai } \\
(n=88)\end{array}$ \\
\hline CNS pažeidimas CSS diagnozavimo metu (\%) & $71 / 83(86)$ & Vienpusis ar abipusis galvos smegenu infarktas (\%) & $46 / 88(52)$ \\
\hline CNS pažeidimas po CSS diagnozavimo (\%) & $10 / 83(12)$ & Hemoragija (\%) & $21 / 88(24)$ \\
\hline CNS pažeidimas prieš CSS diagnozavimą (\%) & $2 / 83(2)$ & Intracerebrinè hemoragija (\%) & $9 / 21(43)$ \\
\hline \multicolumn{2}{|l|}{ Klinikinis pasireiškimas } & Subarachnoidinė hemoragija (\%) & $12 / 21(57)$ \\
\hline Galvos skausmas (\%) & $18 / 85(21)$ & Hematoma pailgosiose smegenyse $(\%)$ & $2 / 88(2)$ \\
\hline Traukuliai $(\%)$ & $2 / 85(2)$ & Demielinizuojantys židiniai (\%) & $2 / 63(3)$ \\
\hline Motorinis deficitas (\%) & $39 / 85(46)$ & Hipertrofinis pachimeningitas (\%) & $2 / 88(2)$ \\
\hline Sensorinis deficitas (\%) & $14 / 85(16)$ & Mielitas (\%) & $1 / 88(1)$ \\
\hline Piramidinis sindromas $(\%)$ & $12 / 85(14)$ & Židiniai, panašūs ị išsėtinès sklerozės židinius (\%) & $1 / 88(1)$ \\
\hline Vestibulinis sindromas $(\%)$ & $3 / 85(4)$ & \multicolumn{2}{|l|}{ Smegenų pažeidimo vietos } \\
\hline Propriorecepcinė ataksija (\%) & $1 / 85(1)$ & Pakaušinė skiltis (\%) & $13 / 69(19)$ \\
\hline Eisenos sutrikimai (\%) & $13 / 85(15)$ & Frontalinè ir ar parietalinė skiltis (\%) & $18 / 69(26)$ \\
\hline Fascikuliacijos (\%) & $1 / 85(1)$ & Smegenų kamienas (\%) & $7 / 69(10)$ \\
\hline Kurtumas (\%) & $1 / 85(1)$ & Temporalinė skiltis (\%) & $7 / 69(10)$ \\
\hline Smegenèlinè ataksija (\%) & $5 / 85(6)$ & Smegenèlès (\%) & $6 / 69(9)$ \\
\hline Kalbos sutrikimai (\%) & $8 / 85(9)$ & Pusovalusis centras (\%) & $5 / 69(7)$ \\
\hline Psichiatriniai sutrikimai (\%) & $23 / 85(27)$ & Vidurinès smegenų arterijos baseinas (\%) & $4 / 69(6)$ \\
\hline Sumišimas (\%) & 9/85 (11) & Didžioji smegenų jungtis (\%) & $1 / 69(1)$ \\
\hline Judèjimo sutrikimai (\%) & $5 / 85(6)$ & & \\
\hline Regèjimo aštrumo sumažèjimas (\%): & $28 / 85(33)$ & & \\
\hline - optinis neuritas (\%) & $15 / 28(54)$ & & \\
\hline - centrinės tinklainės arterijos okliuzija (\%) & $9 / 28(32)$ & & \\
\hline - žievinis aklumas (\%) & $4 / 28(14)$ & & \\
\hline Galvinių nervų pažeidimas (visi) (\%) & $29 / 85(34)$ & & \\
\hline $\begin{array}{l}\text { Galvinių nervų pažeidimas (išskyrus optinị } \\
\text { neuritą) (\%): }\end{array}$ & $18 / 85(21)$ & & \\
\hline - veidinis nervas $(\%)$ & $11 / 29(38)$ & & \\
\hline - judinamasis akies nervas (\%) & $5 / 29(17)$ & & \\
\hline - trišakis nervas (\%) & $3 / 29(10)$ & & \\
\hline - prieangio ir sraigės nervas (\%) & $1 / 29(3)$ & & \\
\hline • liežuvinis ryklès nervas (\%) & $1 / 29(3)$ & & \\
\hline - klajoklis nervas (\%) & $1 / 29(3)$ & & \\
\hline
\end{tabular}

Pagal André R. ir kt. (2017).

- Dažniausia nervų sistemos pažaidos išraiška, sergant CSS, yra periferinė galūnių polineuropatija. Dauginės galvinių nervų neuropatijos pasireiškia labai retai.

- CSS patogenezinis gydymas - gliukokortikoidai ir imunosupresantai. Taip pat skiriamas simptominis gydymas pagal klinikinę išraišką.

\section{Literatūra}

1. Churg J, Strauss L. Allergic granulomatosis, allergic angiitis, and periarteritis nodosa. Am J Pathol 1951; 27(2): 277-301.

2. Pagnoux C, Guilpain P, Guillevin L. Churg-Strauss syndrome. Curr Opin Rheumatol 2007; 19: 25-32. https://doi.org/10.1097/BOR.0b013e3280119854

3. Greco A, Rizzo MI, De Virgilio A, et al. Churg-Strauss syndrome. Autoimmun Rev 2015; 14: 341-8. https://doi.org/ 10.1016/j.autrev.2014.12.004
4. Sinico RA, Di Toma L, Maggiore U, et al. Prevalence and clinical significance of antineutrophil cytoplasmic antibodies in Churg-Strauss syndrome. Arthritis Rheum 2005; 52: 2926-35. https://doi.org/10.1002/art.21250

5. Sable-Fourtassou R, Cohen P, Mahr A, et al. Antineutrophil cytoplasmic antibodies and the Churg-Strauss syndrome. Ann Intern Med 2005; 143: 632-8. https://doi.org/10.7326/ 0003-4819-143-9-200511010-00006

6. Keogh KA, Specks U. Churg-Strauss syndrome: clinical presentation, antineutrophil cytoplasmic antibodies, and leukotriene receptor antagonists. Am J Med 2003; 115: 284-90. https://doi.org/10.1016/S0002-9343(03)00359-0

7. Cattaneo L, Chierici E, Pavone L, et al. Peripheral neuropathy in Wegener's granulomatosis, Churg-Strauss syndrome and microscopic polyangiitis. J Neurol Neurosurg Psychiatry 2007; 78: 1119-23. https://doi.org/10.1136/jnnp. 2006.111013 
8. Roufosse F, Klion AD, Weller PF. Hypereosinophilic syndromes: clinical manifestations, pathophysiology, and diagnosis. https://www.uptodate.com/contents/ hypereosinophilic-syndromes-clinical-manifestationspathophysiology-and-diagnosis. Accessed February 16, 2019.

9. Cho HJ, Yune S, Seok JM, et al. Clinical characteristics and treatment response of peripheral neuropathy in the presence of eosinophilic granulomatosis with polyangiitis (Churg-Strauss syndrome): experience at a single tertiary center. J Clin Neurol 2017; 13(1): 77-83. https://doi.org/10.3988/jen.2017.13.1.77

10. Wolf J, Bergner R, Mutalib S, et al. Neurologic complications of Churg-Strauss syndrome - a prospective monocentric study. Eur J Neurol 2010; 17(4): 582-8. https://doi.org/10.1111/j.1468-1331.2009.02902.x

11. André R, Cottin V, Saraux JL, et al. Central nervous system involvement in eosinophilic granulomatosis with polyangiitis (Churg-Strauss): report of 26 patients and review of the literature. Autoimmun Rev 2017; 16(9): 963-9. https://doi.org/10.1016/j.autrev.2017.07.007

12. Mencacci NE, Bersano A, Cinnante CM, et al. Intracerebral haemorrhage, a possible presentation in Churg-Strauss syndrome: case report and review of the literature. J Neurol Sci 2011; 301(1-2): 107-11. https://doi.org/10.1016/j.jns. 2010.10.016

13. Tokumaru AM, Obata T, Kohyama S, et al. Intracranial meningeal involvement in Churg-Strauss syndrome. AJNR Am J Neuroradiol 2002; 23(2): 221-4.

14. Kumazawa K, Sobue G, Aizawa I, et al. Autonomic dysfunction in vasculitic neuropathy - special reference to sudomotor function. Rinsho Shinkeigaku 1990; 30: 599-604.

15. Tsuda $H$, Ishikawa $H$, Majima $T$, et al. Isolated oculomotor nerve palsy in Churg-Strauss syndrome. Intern Med 2005; 44: 638-40. https://doi.org/10.2169/internalmedicine.44.638
16. Liou HH, Liu HM, Chiang IP, et al. Churg-Strauss syndrome presented as multiple intracerebral hemorrhage. Lupus 1997; 6: 279-82. https://doi.org/10.1177/096120339700600312

\section{G. Rutkauskaitė, R. Masaitienė, J. Dadonienė, D. Jatužis}

\section{MULTIPLE CRANIAL NEUROPATHIES IN CHURG-STRAUSS SYNDROME: CASE REPORT}

\section{Summary}

Churg-Strauss syndrome (CSS), known as eosinophilic granulomatosis with polyangiitis, is a systemic small- to medium-sized vasculitis, characterized by chronic rhinosinusitis, asthma and eosinophilia. Churg and Strauss first described this syndrome in 1951. Histology of CSS usually discloses eosinophil-rich infiltrates, necrotising vasculitis, and eosinophilic-granulomatous inflammation. There are no clear pathophysiologic mechanisms that explain the development of CSS but association between CSS and HLA-DRB4 has been reported. Because of the frequent positivity of antineutrophil cytoplasmic antibodies (ANCAs), which are found in 30-40\% of the cases, CSS has been grouped with ANCA-associated vasculitis. Nervous system manifestations are found in up to $70 \%$ of CSS patients, while cranial neuropathies are rarely diagnosed. Patients are treated with glucocorticoids and immunosuppressants. We describe a case report of a 68-year-old woman with a clinical diagnosis of ChurgStrauss syndrome and multiple cranial neuropathies.

Keywords: Churg-Strauss syndrome, eosinophilic granulomatosis with polyangiitis, ANCA-associated vasculitis, multiple cranial neuropathies, polyneuropathy.

Gauta:

Priimta spaudai:

20190705 20190709 